\title{
Short communication: \\ Anatomical changes in the roots, rhizomes and leaves of seagrass (Cymodocea serrulata) in response to lead
}

\author{
DWI ROSALINA $^{1, \bullet}$, ENDANG YULI HERAWATI ${ }^{2}$, MUHAMMAD MUSA ${ }^{2}$, DINI SOFARINI ${ }^{3}$, YENNY RISJANI $^{2}$ \\ ${ }^{1}$ Department of Marine Engineering, Politeknik Kelautan dan Perikanan Bone. Jl. Sungai Musi, Pallette, Bone 92719, South Sulawesi, Indonesia. \\ Tel.: +62-481-2920204, `email: myrafirifky@ gmail.com \\ ${ }^{2}$ Department of Water Resources Management, Faculty of Fisheries and Marine Sciences. Universitas Brawijaya. Jl. Veteran, Malang 65145, East Java, \\ Indonesia \\ ${ }^{3}$ Department of Water Resources Management, Faculty of Fisheries and Marine Sciences, Universitas Lambung Mangkurat. J1. A. Yani Km 36, \\ Banjarbaru 70124, South Kalimantan, Indonesia
}

Manuscript received: 8 July 2019. Revision accepted: 21 August 2019.

\begin{abstract}
Rosalina D, Herawati EY, Musa M, Sofarini D, Risjani Y. 2019. Short communication: Anatomical changes in the roots, rhizomes, and leaves of seagrass (Cymodocea serrulata) in response to lead. Biodiversitas 20: 2583-2588. Runoff of heavy metals as a result of urban and industrial development is a potential threat for seagrass populations in the coast. The objectives of this study were to study the anatomical changes in the tissues of roots, rhizomes, and leaves of seagrass Cymodocea serrulata in response to treatment with different concentrations of lead $(\mathrm{Pb})$ for different time durations. This experiment used heavy metal $\mathrm{Pb}$ from a solution of $\mathrm{Pb}\left(\mathrm{NO}_{3}\right)^{2-}$ with a concentration of $0 \mathrm{ppm}, 5 \mathrm{ppm}, 10 \mathrm{ppm}$, and $15 \mathrm{ppm}$ and the treatment period extended up to 4 weeks with 3 replications. Analysis of changes in anatomical features showed that exodermis and endodermis cells in the roots thickened as lead concentration increased. The air spaces in the root cortex and rhizome also widened. Thickening of cell walls occurred in the epidermis and endodermis of rhizome. Likewise, in the leaves, thickening occurred in the upper and lower cuticle and also the upper and lower epidermis. In general, changes in anatomical features of root, rhizome, and leaves were observed in response to increasing lead concentrations. The results showed that $C$. serrulata developed some level of tolerance to heavy metals, especially lead.
\end{abstract}

Keywords: Accumulation, anatomy, Cymodocea serrulata, lead

\section{INTRODUCTION}

The phytotoxic effects of heavy metals in plants were seen in visual symptoms such as chlorosis, necrosis and wilt through a reduction in growth and accumulation of biomass (Marques et al. 2000; Sanitá di Troppi and Gabbrielli 1999). Physiological effects also noted in plants exposed to contamination, at various levels of photosynthesis, including chlorophyll biosynthesis (Chugh and Sawhney 1999). When heavy metals penetrated the roots, they partially accumulated and were translocated in cell wall (MacFarlane and Burchett 2000; Rosalina et al. 2018), with exodermis and endodermis in seagrass plant tissues which were effective barriers to the movement of these ions (Ederli et al. 2004; Lux et al. 2004; Wójcik et al. 2005; Rosalina et al. 2018).

Accumulation and localization of $\mathrm{Cd}$ appeared as dense granules in the roots of Agrostis gigantea and Zea mays (Rauser and Ackerley 1987), as cell wall deposit on the roots of Zea mays (Khan et al. 1984) and Phaseolus vulgaris L. cv. Contender (Vazquez et al. 1992b). Metal absorption and accumulation at higher concentrations could be cytotoxic in some plant species, causing structural and ultrastructural changes that affected plant growth and physiological well-being (Barceló et al. 1988; Vazquez et al. 1992a; Zhao et al. 2000; Han et al. 2004). Zn hyperaccumulation resulted in mesophyll cell size decrease in Arabidopsis haleri (Zhao et al. 2000) while Cd accumulation caused the breakdown of chloroplasts in Phaseolus vulgaris L. ev. Contender (Barceló et al. 1988) and reduced plant growth in Brassica juncea (Haag-Kerwer et al. 1999).

Brix and Lyngby (1983), and Nienhuis (1986) stated that seagrasses had the ability to accumulate heavy metals in marine waters. Seagrasses absorb heavy metals present in sea waters through their leaves, rhizomes, and roots, and they could also be used as bioindicators to monitor the presence of heavy metals (Pulich 1980; Lyngby and Brix 1982, 1983; Nienhuis 1986; Ward 1989). Further study of the anatomical changes that occurred in seagrass tissue (roots, rhizomes, and leaves) in response to heavy metals would help to understand the process of their accumulation and also heavy metal tolerance.

\section{MATERIALS AND METHODS}

This research was carried out in February 2018. Healthy seagrasses belonging to the species Cymodocea serrulata having the same number of leaves and vertical internodes which look almost similar were used in this study. These sample seagrass plants had 3-4 leaves whose width was $0.5-0.8 \mathrm{~cm}$ and length was $6.2-22.5 \mathrm{~cm}$. The experimental 
specimens were placed in 12 aquariums were $30 \mathrm{~cm}$ long, $30 \mathrm{~cm}$ wide and $25 \mathrm{~cm}$ high. Each of them was filled with 30 seagrasses for 4 weeks. The plants were exposed to lead from $\mathrm{Pb}\left(\mathrm{NO}_{3}\right)_{2}$ solutions at $0,5,10$, and $15 \mathrm{ppm}$ concentrations for 4 weeks, with 3 repetitions for each treatment. They were observed at the $1^{\text {st }}, 2^{\text {nd }}, 3^{\text {rd }}$, and $4^{\text {th }}$ week, in accordance with Tupan and Azrianingsih (2016). The research was conducted at the Biology Laboratory, Faculty of Mathematics and Sciences, University of Brawijaya, Malang, Indonesia. anatomical observations and photomicrography of seagrass anatomical sections were carried out at the Biomolecular Laboratory, Faculty of Mathematics and Sciences, University of Brawijaya, Malang, Indonesia.

\section{Procedures: Histological preparations}

To test seagrass tissue histologically, C. serrulata seagrass samples were taken out from experimental aquariums every week. The seagrass parts were separated as roots, rhizomes and leaves, cleaned with distilled water and then immersed in a solution of FAA (90 ml from $70 \%$ ethyl alcohol: $5 \mathrm{ml}$ formaldehyde: $5 \mathrm{ml}$ acetic acid) which functions as a fixative. The preparation was according to modified method of Ruzin (1999). The histological preparations used fresh preparations fixed and cross-linked using stainless steel and placed between two cassava or carrot cork blocks using a microtome (Euremex MT.5503 clamp on the hand microtome). After being cut thin, the sections were immersed $1 \%$ safranine for approximately 5 minutes. After safranine staining, the sections were rinsed with distilled water to remove any impurities attached to the sections. The sections were then mounted on slide in glycerin, and covered a glass cover. The anatomical observations were performed using a light microscope. Measurement of thickness of exodermis and endodermis of root, thickness of epidermis and endodermis of rhizome, as well as thickness of cuticle and epidermis of both abaxial and adaxial section of leaves was performed using the Olympus BX51 Digital Imaging Microscope.

\section{Data analysis}

Result about the thickness of the exodermis and endodermis of root, thickness of the epidermis and endodermis of rhizome, as well as thickness of the cuticle and epidermis of both abaxial and adaxial side of leaves were analyzed using One Way ANOVA at 95\% significance $(\mathrm{p}<0.05)$. If the results showed a significant difference, then proceeded with the Least Significant Difference Test (LSD) at the level of 95\%. Data were analyzed using SPSS version 21 program. Data were tested for normality, homogeneity, and non-additives before analysis, as a condition for ANOVA test.

\section{RESULTS AND DISCUSSION}

\section{Anatomical changes of Cymodocea serrulata roots in response to lead}

The effect of different concentration of lead on the thickness of exodermis and endodermis of roots of $C$. serrulata is given in Table 1 . The effect of $15 \mathrm{ppm}$ of lead, when compared to control $(0 \mathrm{ppm})$ on the anatomical features of roots, is shown in Figure 1.

Accumulation of lead in the root tissue of $C$. serrulata showed changes in the tissues affected by lead. Exodermis and endodermis thickness changed with increasing lead concentration and length or duration of exposure. Increased concentration lead resulted in a decrease in the thickness of exodermis of the roots. According to Al-Saadi et al. (2013), lead metal accumulation increased along with increasing concentration of heavy metals. During stress, the root growth rate decreased, and exodermis and endodermis would develop closer to the root tip, indicating that stress accelerated the development of exodermis and endodermis (Enstone et al. 2003). On the other hand, reduction in root growth happened due to a decrease in cell division as a result of increased cell wall thickness exposed to heavy metals (Stohs et al. 2000). The higher of the lead cause the thicker exodermis and endodermis cells in the seagrass roots (Figure 1). This showed that lead metal accumulation could accelerate the maturation of exodermal and endodermal cell walls. According to Enstone et al. (2003), the root with mature exodermis is a barrier to the entry of apoplast ions found near the root surface. Changes in size, and cell form showed disturbances in heavy metals in cell maturation at the root and disrupts hormonal balance (Barceló and Poschenrieder 1990; Sandalio et al. 2001). Metals absorbed in the cell wall and the intercellular space of the cortical parenchyma at the root was one of the strategies of seagrass for self-defense (Gomes et al. 2011).

Table 1. Thickness of endodermis and exodermis of roots of Cymodocea serrulata treated with different concentrations of lead

\begin{tabular}{|c|c|c|c|c|c|}
\hline \multirow{2}{*}{ Roots tissue } & \multirow{2}{*}{$\begin{array}{c}\text { Lead concentration } \\
(\mathbf{p p m})\end{array}$} & \multicolumn{4}{|c|}{ Week } \\
\hline & & 1 & 2 & 3 & 4 \\
\hline \multirow[t]{4}{*}{ Exodermis thickness $(\mu \mathrm{m})$} & 0 & $25.41 \pm 3.09$ & $27.17 \pm 6.09$ & $27.95 \pm 5.53$ & $29.29 \pm 5.10$ \\
\hline & 5 & $22.89 \pm 4.23$ & $25.16 \pm 3.54$ & $27.59 \pm 4.50$ & $29.47 \pm 4.32$ \\
\hline & 10 & $26.71 \pm 4.01$ & $27.88 \pm 4.32$ & $28.66 \pm 3.16$ & $30.22 \pm 3.59$ \\
\hline & 15 & $23.30 \pm 4.45$ & $26.01 \pm 2.07$ & $26.37 \pm 4.64$ & $28.04 \pm 4.13$ \\
\hline \multirow[t]{4}{*}{ Endodermis thickness $(\mu \mathrm{m})$} & 0 & $6.52 \pm 1.27$ & $8.40 \pm 1.07$ & $9.10 \pm 1.22$ & $9.25 \pm 1.35$ \\
\hline & 5 & $7.48 \pm 1.50$ & $8.22 \pm 1.19$ & $9.26 \pm 1.52$ & $9.30 \pm 1.22$ \\
\hline & 10 & $8.94 \pm 1.08$ & $9.81 \pm 1.37$ & $10.09 \pm 1.65$ & $10.24 \pm 1.54$ \\
\hline & 15 & $9.44 \pm 1.26$ & $9.94 \pm 1.74$ & $9.92 \pm 1.72$ & $10.64 \pm 1.60$ \\
\hline
\end{tabular}




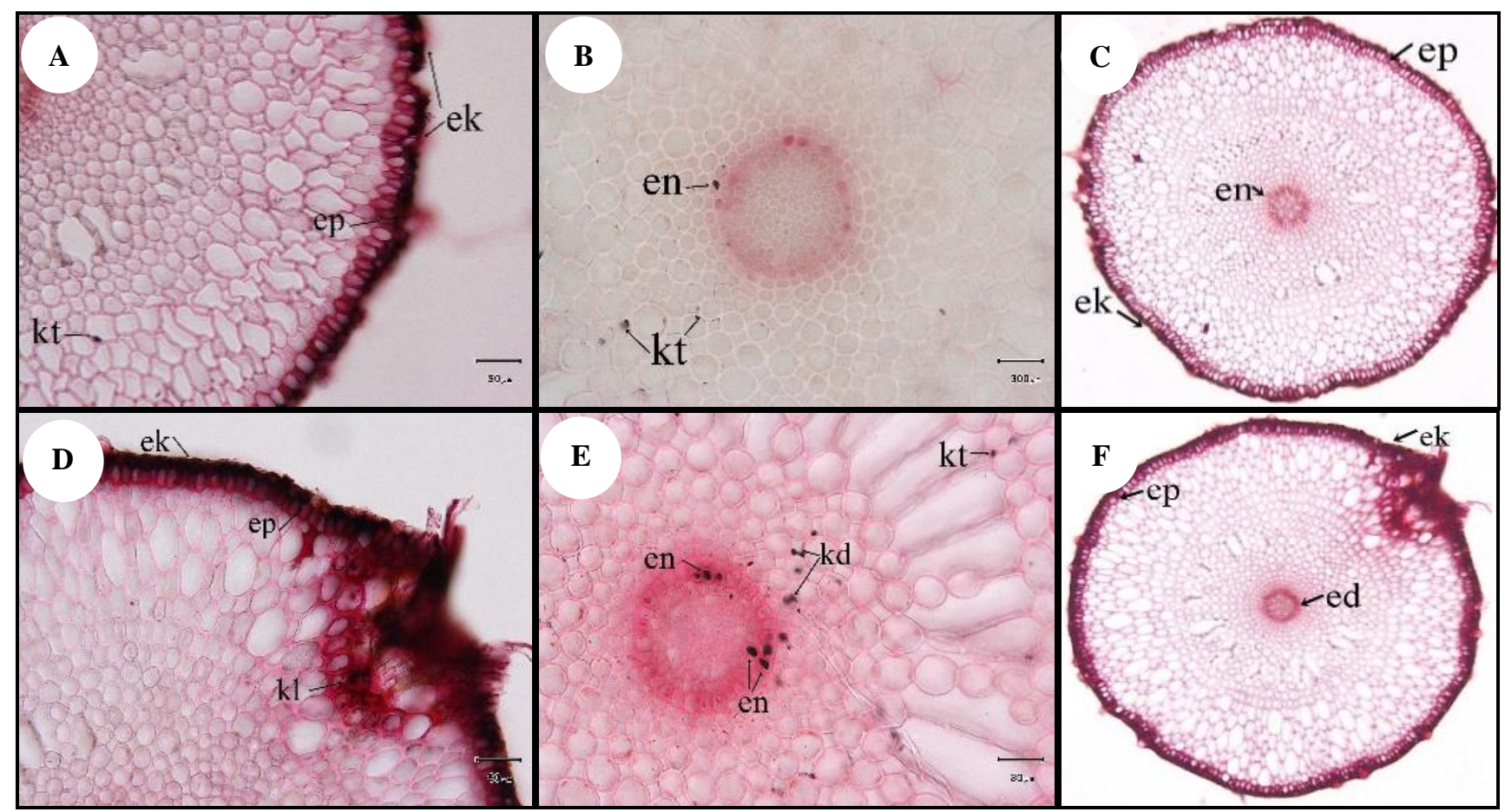

Figure 1. Anatomical features of roots at $15 \mathrm{ppm}$ of lead treatment and control (0 ppm); A, B, C show thickness of ek (exodermis), ed (endodermis) and kt (middle cortex) in the control (arrow). D, E, F show changes in thickening of ek (exodermis), ed (endodermis), kt (middle cortex), kd (inner cortex) at 15 ppm lead treatment (arrow)

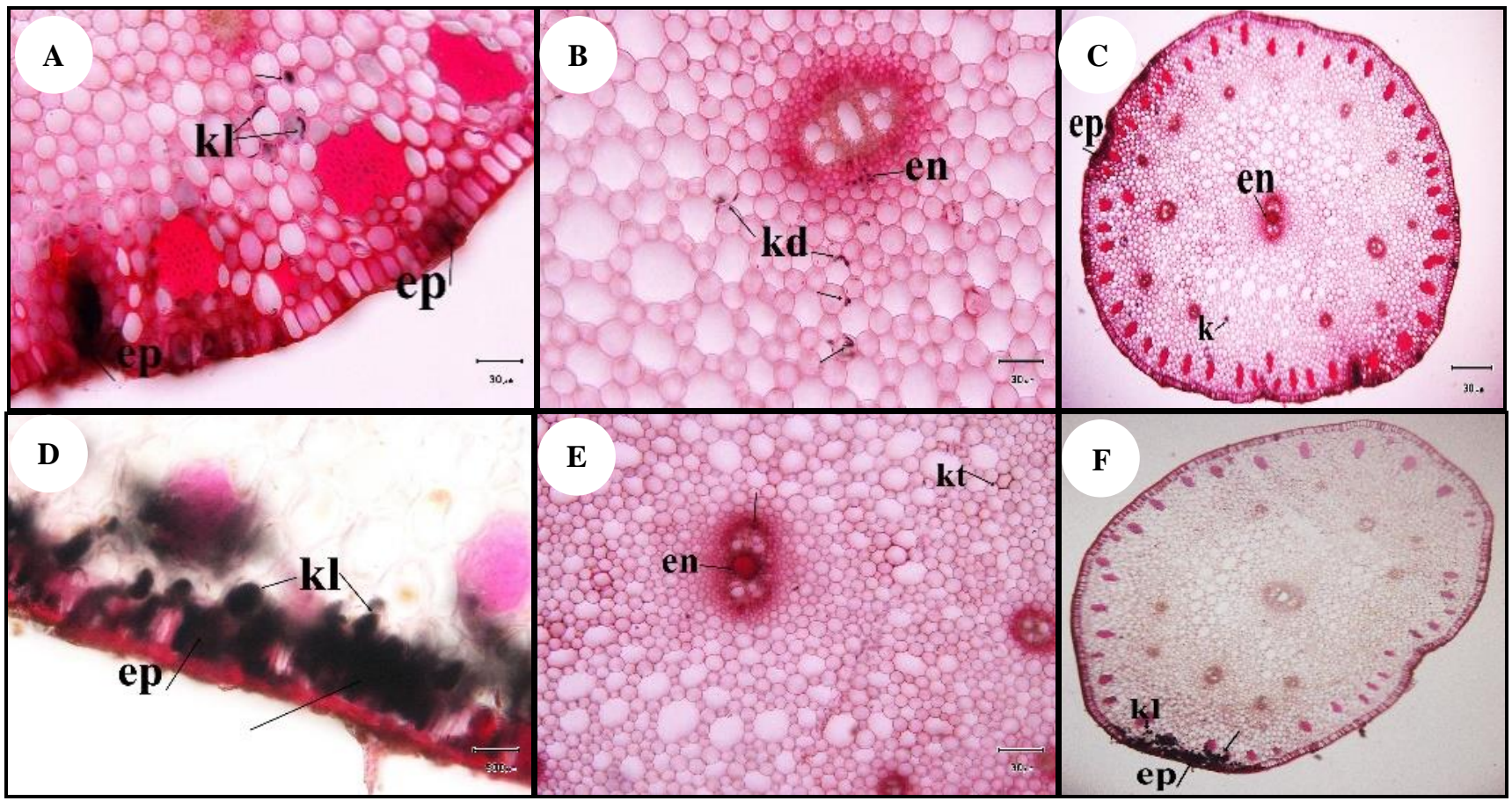

Figure 2. Changes in anatomical structure of rhizome at $15 \mathrm{ppm}$ lead treatment, compared with control (0 ppm); A, B, C shows changes in ep (epidermis), ed (endodermis), kd (inner cortex) and airspace (cortex) in the control (arrow). D, E, F shows changes in thickening of ep (epidermis), ed (endodermis), $\mathrm{kl}$ (outer cortex) at $15 \mathrm{ppm}$ lead treatment (arrow) 


\section{Anatomical changes in Cymodocea serrulata rhizome in response to lead}

The concentration of $5 \mathrm{ppm}$ of lead resulted in the lowest change of exodermis structure in the epidermis which was significantly different from the changes at a concentration of 10 and $15 \mathrm{ppm}$. However, it was not significantly different from the concentration of $0 \mathrm{ppm}$. It was found that the changes in the 2 nd week of treatment were lower than that in the 4th week (Table 2). The effect of lead on the anatomy of seagrass rhizome is shown in Figure 2.

Increased concentration lead resulted in increase in thickness of the epidermis and endodermis of the rhizome. Changes in epidermis and endodermis tissue and thickening of the cell wall layers (Figure 2) were the result of accumulation of heavy metals in seagrass epidermal and endodermis tissues resulting in faster cell maturation and thickening of tissues. Thickening of epidermis and endodermis cells in the rhizome was an adaptation to prevent the translocation of lead metal to other tissues. Cortex cells in the rhizome showed changes in the air space. Air space was enlarged due to reduce diaphragm.
Cortex cells consisted of pseudohypodermis and aerenchyma tissue. According to Al-Saadi (2013), changes in size, shape of cortical parenchyma cells occur due to the accumulation of heavy metals. The higher concentration of heavy metals would expand the cell space in the parenchyma cells of the cortex and reduce the vascular bundles. In Potamogeton crispus and P. perfoliatus, the thickening of the walls of both xylem elements and tissues accumulating metals, and of cortical parenchyma thickening were the other anatomical adaptations for heavy metal toxicity (Vazquez et al. 1992).

\section{Anatomical analysis of Cymodocea serrulata leaves}

In the abaxial cuticle of seagrass leaves, the lowest average change in thickness was observed at the concentration of $5 \mathrm{ppm}$ and it was significantly different from that of $15 \mathrm{ppm}$ which was the highest (Table 3). Duration-wise, the average change in the abaxial cuticle thickness was the lowest in the 1st week and it was significantly different from that of the 4th week, which was the highest (Table 3).

Table 2. Anatomical changes in rhizome of Cymodocea serrulata exposed to lead

\begin{tabular}{lccccc}
\hline Rhizomes tissue & $\begin{array}{c}\text { Lead concentration } \\
(\mathbf{p p m})\end{array}$ & $\mathbf{1}$ & $\mathbf{2}$ & $\mathbf{3}$ & $\mathbf{4}$ \\
\cline { 3 - 6 } & 0 & $30.55 \pm 4.45$ & $38.30 \pm 4.38$ & $40.22 \pm 6.24$ & $41.73 \pm 7.08$ \\
& 5 & $33.92 \pm 4.75$ & $36.26 \pm 5.44$ & $37.47 \pm 10.65$ & $38.43 \pm 5.33$ \\
$(\mu \mathrm{m})$ & 10 & $37.14 \pm 6.34$ & $38.51 \pm 3.94$ & $39.61 \pm 7.26$ & $44.64 \pm 8.07$ \\
& 15 & $40.10 \pm 4.61$ & $40.44 \pm 5.54$ & $40.89 \pm 9.47$ & $49.26 \pm 8.64$ \\
& & & & \\
Endodermis thickness & 0 & $12.02 \pm 2.23$ & $15.44 \pm 2.02$ & $15.90 \pm 2.45$ & $17.09 \pm 1.94$ \\
$(\mu \mathrm{m})$ & 5 & $13.61 \pm 2.71$ & $13.64 \pm 1.87$ & $14.95 \pm 1.72$ & $15.77 \pm 2.85$ \\
& 10 & $17.39 \pm 1.87$ & $14.36 \pm 2.26$ & $15.92 \pm 2.21$ & $17.39 \pm 1.87$ \\
& 15 & $17.72 \pm 1.82$ & $14.82 \pm 1.95$ & $17.92 \pm 1.78$ & $17.73 \pm 2.42$ \\
\hline
\end{tabular}

Table 3. Anatomical changes in leaves of Cymodocea serrulata exposed to lead

\begin{tabular}{|c|c|c|c|c|c|}
\hline \multirow{2}{*}{ Leaf tissue } & \multirow{2}{*}{$\begin{array}{l}\text { Lead concentration } \\
(\mathbf{p p m})\end{array}$} & \multicolumn{4}{|c|}{ Duration of exposure in weeks } \\
\hline & & 1 & 2 & 3 & 4 \\
\hline \multirow{4}{*}{$\begin{array}{l}\text { Cuticle abaxial } \\
(\mu \mathrm{m})\end{array}$} & 0 & $4.82 \pm 0.884$ & $5.27 \pm 0.69$ & $5.30 \pm 1.61$ & $5.43 \pm 1.01$ \\
\hline & 5 & $4.07 \pm 0.697$ & $4.09 \pm 0.68$ & $4.50 \pm 0.87$ & $4.93 \pm 1.51$ \\
\hline & 10 & $4.38 \pm 0.796$ & $4.56 \pm 0.66$ & $5.17 \pm 0.87$ & $5.62 \pm 0.77$ \\
\hline & 15 & $4.22 \pm 0.723$ & $6.09 \pm 1.16$ & $6.16 \pm 1.12$ & $7.04 \pm 1.82$ \\
\hline \multirow{4}{*}{$\begin{array}{l}\text { Cuticle adaxial } \\
(\mu \mathrm{m})\end{array}$} & 0 & $3.97 \pm 1.17$ & $5.358 \pm 0.84$ & $5.43 \pm 1.02$ & $5.52 \pm 1.02$ \\
\hline & 5 & $3.87 \pm 0.76$ & $4.14 \pm 0.73$ & $4.20 \pm 0.82$ & $4.60 \pm 0.99$ \\
\hline & 10 & $4.12 \pm 0.68$ & $4.37 \pm 0.74$ & $4.83 \pm 1.21$ & $5.89 \pm 1.07$ \\
\hline & 15 & $4.42 \pm 0.68$ & $5.49 \pm 1.48$ & $6.08 \pm 0.68$ & $6.28 \pm 1.78$ \\
\hline \multirow{4}{*}{$\begin{array}{l}\text { Epidermis abaxial } \\
(\mu \mathrm{m})\end{array}$} & 0 & $11.02 \pm 2.77$ & $11.10 \pm 1.64$ & $11.42 \pm 2.14$ & $11.82 \pm 1.33$ \\
\hline & 5 & $11.30 \pm 2.38$ & $11.79 \pm 2.47$ & $11.82 \pm 2.13$ & $12.61 \pm 2.15$ \\
\hline & 10 & $10.99 \pm 2.29$ & $11.47 \pm 2.57$ & $12.01 \pm 4.64$ & $13.02 \pm 1.94$ \\
\hline & 15 & $11.27 \pm 8.33$ & $11.38 \pm .2 .87$ & $12.97 \pm 1.72$ & $13.45 \pm 1.99$ \\
\hline \multirow{4}{*}{$\begin{array}{l}\text { Epidermis adaxial } \\
(\mu \mathrm{m})\end{array}$} & 0 & $10.35 \pm 1.47$ & $11.55 \pm 2.07$ & $12.412 \pm 2.011$ & $12.58 \pm 2.607$ \\
\hline & 5 & $10.913 \pm 2.495$ & $11.248 \pm 1.516$ & $11.613 \pm 1.719$ & $12.839 \pm 1.932$ \\
\hline & 10 & $8.979 \pm 1.510$ & $11.558 \pm 2.367$ & $11.960 \pm 1.642$ & $13.317 \pm 1.995$ \\
\hline & 15 & $10.975 \pm 1.334$ & $12.471 \pm 1.675$ & $12.828 \pm 1.474$ & $13.018 \pm 2.115$ \\
\hline
\end{tabular}




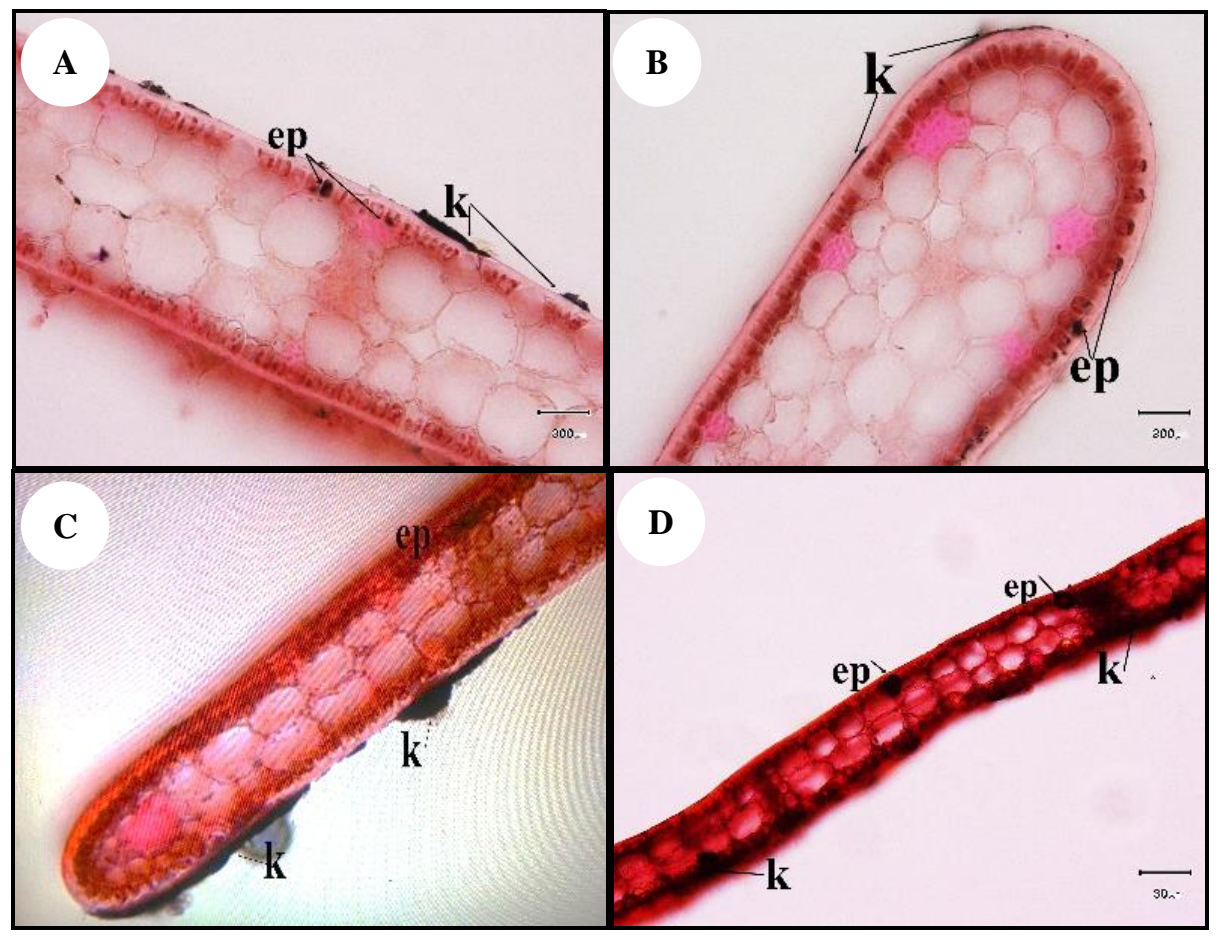

Figure 3. Changes in leaf anatomy at $15 \mathrm{ppm}$ lead, compared with control (0 ppm); A. Cuticle in abaxial and adaxial (k), epidermis in abaxial and adaxial (ep) surfaces in the leaf of control plants(arrow). B. Nature of cuticle in abaxial and adaxial (k), and epidermis in abaxial and adaxial (ep) at $15 \mathrm{ppm}$ lead treatment (arrow)

Adaxial cuticles were the lowest at $10 \mathrm{ppm}$ compared to the highest at $15 \mathrm{ppm}$ concentration. Duration-wise, average changes in the adaxial cuticle thickness in the Ist week was lowest in comparison to the 4 th week which was the highest (Table 3 ). Concentration of $0 \mathrm{ppm}$ produced the lowest average change in the thickness of abaxial epidermis compared to the highest change observed in concentration of $15 \mathrm{ppm}$. It was lowest in week 1 period compared to the highest in week 4 concentration of $10 \mathrm{ppm}$ resulted in the lowest changes in the adaxial epidermal structure compared to $15 \mathrm{ppm}$ (Table 3 ). The effect of lead on leaf anatomy can be seen in Figure 3.

Analysis of anatomical structure in seagrass leaves in response to lead showed changes in the cuticle layer and thickening of epidermis cells according to the concentrations of lead (Figure 3). Increased concentration lead resulted in an increase in the thickness of the abaxial cuticle and increased concentration of lead resulted in an increase in adaxial epidermal thickness. Aquatic plants submerged in water could absorb nutrients, including metals, through their parts including leaves and absorption was influenced by the structure and permeability of cuticle layer. The mechanism of the entry of lead metal into leaf tissue is through leaf stomata because the size of leaf stomata was greater than the size of lead metal (Tomlinson 1980; Kuo 1983). The seagrass species $C$. serrulata did not have any stomata but had thin and oval, hollow cuticle. This cuticle served as the entry pathway for lead metal into seagrass leaves. The thickenings developed in the cuticle and epidermis of seagrass in response to lead may be one of the self-defense mechanisms. According to Sandalio (2001), heavy metals could induce oxidative stress. In the leaves of Pisum sativum, physiological responses to heavy metals related to oxidative stress, such as cell disorders characterized by increased mesophyll cell size, reduction in inter-cell space and disruption in the structure of chloroplasts (Sandalio 2001). Shaw (1995) reported that heavy metals $\mathrm{Cd}$ and $\mathrm{Hg}$ resulted in detrimental effects, especially on the membrane, in Phaseolus aureus. Al-Saadi (2013) showed that Potamogeton leaves responded to the presence of heavy metals by a reduction in epidermal cell size and aerenchyma tissue.

In conclusion, lead was found accumulating in every part of seagrasses (Cymodocea serrulata) such as roots, rhizomes and leaves and the higher the concentration of lead, thicker was the tissue, especially the epidermis and endodermis. This may be one of the strategies of seagrass to minimize the spread of heavy metal to other tissues

\section{ACKNOWLEDGEMENTS}

The researchers would like to thank the Ministry of Research, Technology and Higher Education which funded this Research in Earliest Lecturer Research Scheme for the Fiscal Year 2017. Contract No.: 060/SP2H/LT/DRPM/IV/ 2017. 


\section{REFERENCES}

Al-Saadi SAAM, Al-Asaadi WM, Al-Waheeb ANH. 2013. The effect of some heavy metals accumulation on physiological and anatomical characteristic of some Potamogeton L. plant. J Ecol Environ Sci 4(1): 100-108.

Barceló J, Vazquez MD, Poschenrieder C. 1988. Cadmium induced structural and ultrastructural changes in the vascular system of bush bean stems. Bot Acta 101: 254-261.

Barceló J., Poschenrieder C. 1990. Plant water relations as affected by heavy metal stress: a review. J Plant Nutr 13:1-37.

Brix H, Lyngby EJ. 1983. The distribution of some metallic elements in eelgrass (Zostera marina L.) and sediment in the Limfjiord, Denmark Estuar Coast Shelf Sci 16: 455-467.

Chugh LK, Sawhney SK. 1999. Photosynthetic activities of Pisum sativum seedlings grown in presence of cadmium. Plant Physiol Biochem 37: 297-303.

Ederli L, Reale L, Ferranti F, Pasqualini S. 2004. Responses induced by high concentration of cadmium in Phragmites australis roots. Physio Plant 121: 66-74.

Enstone DE, Peterson CA, Ma F. 2003. Root endodermis and exodermis: Structure, function, and responses to the environment. J Plant Growth Regul 21: 335-351.

Gomes MP, Marques TC, Nogueira MO, Castro EM, Soares AM. 2011 Ecophysiological and anatomical changes due to uptake and accumulation of heavy metal in Brachiaria decumbens. Sci Agric 68 (5): 566-573

Haag-Kerwer A, Schafer HJ, Heiss S, Walter C, Rausch T. 1999. Cadmium exposure in Brassica juncea causes a decline in transpiration rate and leaf expansion without effect on photosynthesis. J Exp Bot 50: 1827-1835.

Han FX, Maruthi Sridhar BB, Monts DL, Su Y. 2004. Phytoavailability and toxicity of trivalent and hexavalent chromium to Brassica juncea L. Czern. New Phytol 162: 489-499.

Khan DH, Duckett JG, Frankland B, Kirkham JB. 1984. An X-ray microanalytical study of the distribution of cadmium in roots of $\mathrm{Zea}$ mays L. J Plant Physiol 115: 19-28.

Kuo S, Heilmen PE. Baker AS. 1983. Distribution and forms of copper, zinc, cadmium, iron, and manganese in soils near a copper smelter. Soil Sci 135: 101-109.

Lyngby EJ, Brix H. 1982. Seasonal and environmental variation in cadmium, copper, lead and zinc concentrations in eelgrass (Zostera marina L.) in the Limfjork Denmark. Aquat Bot 14: 59-74.

Lyngby EJ, Brix H. 1983. Seasonal changes in the concentration of Ca, $\mathrm{Fe}, \mathrm{K}, \mathrm{Mg}, \mathrm{Mn}$ and $\mathrm{Na}$ in eelgrass (Zostera marina L.) in the Limfjiord, Denmark. Aquat Bot 17: 107-117.

Lux AA, Sottniková A, Opatrná J, Greger M. 2004. Differences in structure of adventitious roots in Salix clones with contrasting characteristics of cadmium accumulation and sensitivity. Physiol Plant 120: 537-545.
MacFarlane GR, Burchett MD. 2000. Cellular distribution of copper, lead and zinc in the grey mangrove, Avicennia marina (Forsk.) Vierh. Aquat Bot 68: 45-59.

Marques TCLLSM, Moreira FMS, Siqueira JO. 2000. Growth and uptake of metals in tree seedlings in soil contaminated with heavy metals. Pesqu Agropecu Bras 35: 121-132. [Portuguese]

Nienhuis PH. 1986. Background levels of heavy metals in nine tropical seagrass species in Indonesia. Mar Pollut Bull 17: 508-511.

Pulich WM, Jr. 1980. Heavy metal accumulation by selected Halodule wrightii Aschers. populations in the Corpus Christi Bay area. Contrib Mar Sci 23: 89-100.

Rauser WE, Ackerley CA. 1987. Localization of cadmium in granules within differentiating and mature root cells. Can J Bot 65: 643-646.

Ruzin SE. 1999 Plant Microtechnique and Microscopy. Oxford University Press, NewYork.

Rosalina D, Endang Y H, Musa M, Risjani Y. 2018. Lead (Pb) adsorption in roots, rhizomes, and leaves of seagrass Cymodocea serrulata. Fresenius Environ Bull 27 (12): 9156-9166.

Sandalio LM, Dalurzo HC, Gomez M, Romero-Puertas MC, del Rio LA. 2001. Cadmium induced changes in the growth and oxidative metabolism of pea plants. J Exp Bot 52: 2115-2126.

Sanitá di Troppi L, Gabbrielli R. 1999. Response to cadmium in higher plants. Environ Exp Bot 41: 105-130.

Shaw BP. 1995. Effects of mercury and cadmium on the activities of antioxidative enzymes in the seedlings of Phaseolus aureus. Biol Plant 37: 587. DOI: 10.1007/BF02908843.

Stohs SJ, Bagchi D, Hassoun E, Bagchi M. 2000. Oxidative mechanisms in the toxicity of chromium and cadmium ions. J Environ Pathol Toxicol Oncol 19: 201-213.

Tomlinson DC, Wilson JG, Harris CR, Jeffery DW. 1980. Problems in the assessment of heavy metals levels in estuaries and the formation of a pollution index. Helgol Wiss Meeresunters 33: 566-575

Vazquez MD, Barcelo J, Poschenrieder CH, Madico J, Hatton P, Baker AJM, Cope GH. 1992a. Localization of zinc and cadmium in Thlaspi caerulescens (Brassicaceae), a metallophyte that can hyper accumulate both metals. J Plant Physiol 140: 350-355.

Vazquez MD, Poschenrieder CH, Barcelo J. 1992b. Ultrastructural effects and localization of low cadmium concentrations in bean roots. New Phytol 120: 215-226.

Ward TJ. 1989. The accumulation and effects of metals in seagrass habitats. In: Larkum AWD, McComb AJ, Shepherd SA (eds.) Biology of Seagrasses: A Treatise on the Biology of Seagrasses with Special Reference to the Australian Region. Elsevier, Amsterdam.

Wójcik M, Vangronsveld J, D’Haen J, Tukiendorf A. 2005. Cadmium tolerance in Thlaspi caerulescens. Environ Exp Bot 53: 163-171.

Zhao FJ, Lombi E, Breedon T, McGrath SP. 2000. Zinc hyperaccumulation and cellular distribution in Arabidopsis halleri. Plant Cell Environ 23: 507-514. 